\title{
基于信息熵的乡村生产空间系统演化 及其可持续发展能力
}

\author{
何炎洲,王 成 \\ (西南大学地理科学学院/乡村人居环境研究实验室/岩溶环境重庆市重点实验室，重庆 400715)
}

\begin{abstract}
摘要：乡村生产空间系统演化是乡村生产空间系统内部及其与外部系统间进行物质、能量和 信息交换的表征或结果,这一结果的优劣是实现系统可持续发展的内生物质基础与保障。以 重庆市为研究区, 以 2001-2015 年为研究时段, 基于信息熵, 从支持型输人熵、压力型输出熵、氧 化型代谢熵、还原型代谢熵四个方面构建乡村生产空间系统演化指标体系, 揭示乡村生产空间 系统的演变规律和可持续发展能力, 探析乡村生产空间系统熵变与可持续发展能力之间协同 演化过程中的相关关系, 设计乡村生产空间系统优化路径。结果表明: (1)2001-2015年重庆市 乡村生产空间系统熵流为 $0.017 \sim 0.049$, 摘产生为 $0.204 \sim 0.059$, 均呈下降趋势, 乡村生产空间 系统的协调性和活力得以增强; 总熵变为 $0.221 \sim 0.010$, 呈相同趋势, 乡村生产空间系统有序度 不断提高, 总体上向健康水平发展。(2)2001-2015 年重庆市乡村生产空间系统可持续发展能力 得分为 1.285 2.803, 呈上升趋势, 系统可持续发展态势良好, 并不断向可持续方向演进。(3)可 持续发展能力得分与支持型输人熵、还原型代谢熵正相关, 与压力型输出熵、氧化型代谢熵负 相关,与熵流、熵产生和总熵变负相关。
\end{abstract}

关键词：乡村生产空间系统;信息熵;演化;可持续发展能力;重庆市

乡村生产空间系统作为人地关系地域系统的多种形式之一，是乡村多元主体在乡村 生产空间中，通过开展各种生产活动，形成复杂的社会经济关系，具有一定结构形态和 功能组合机制的空间集合体，是一动态结构 ${ }^{[1]}$ 。乡村生产空间系统演化是乡村生产空间系 统内部及其与外部系统间进行物质、能量和信息交换的表征或结果，这一结果的优劣是 实现系统可持续发展的内生物质基础与保障。目前, 中国乡村地域 “要素一结构一功 能”、空间格局、经济形态和社会关系等正发生着深刻的变革 ${ }^{[2]}$, 乡村生产空间系统逐渐 呈现出主体的多元 ${ }^{[3]}$ 、客体（生产用地）的压缩 ${ }^{[4]}$ 、环境的衰退 ${ }^{[1]}$ 等新时代特征。如何探 析乡村生产空间系统的演化规律和可持续发展能力, 揭示其协同演化进程中的相关关 系, 优化乡村生产空间系统, 对于建立可持续的内生机制以践行乡村振兴战略具有重要 价值。然而，学界对于乡村生产空间系统的研究尚处于起步阶段 ${ }^{[1,6]}$ 。信息熵作为系统有 序程度的一种度量, 可以用来揭示系统发展演化方向 ${ }^{[7]}$ 。在国外, 信息熵已尝试应用在模 拟土壤粒径分布 ${ }^{[8]}$ 、城市水资源时空分异与管理 ${ }^{[9]}$ 、景观格局变化分析 ${ }^{[7]}$ 、城市经济系统 质量增长 ${ }^{[10]}$ 以及数据集成与模型演化 ${ }^{[1]}$ 等领域; 在国内, 信息熵主要应用在探索土地利 用结构的时空演化规律与预测 ${ }^{[12-13]}$ 、影响因素及驱动机制 ${ }^{[14-15]}$ ，区域土地利用系统的有序

收稿日期：2018-11-12；修订日期：2019-02-17

基金项目：国家自然科学基金项目（41741022); 中央高校基本科研业务费专项资金（XDJK2017B016）

作者简介：何炎洲（1992-), 女, 重庆忠县人, 硕士, 主要从事土地利用与乡村发展、乡村人居环境研究。 E-mail: heyanzhouer@126.com

通讯作者: 王成 (1974- ), 男, 重庆荣昌人, 教授, 博士生导师, 主要从事土地利用与乡村发展、乡村人居环境研 究。E-mail: wchorange@126.com 
程度 ${ }^{[16]}$ 、能源消费结构的演变规律 ${ }^{[1]}$ 和城市人口密度的演化分析 ${ }^{[18-19]}$ 等领域。目前, 信息 熵的应用领域已拓展到城市生态系统演化及其可持续发展能力 ${ }^{[20-21]}$, 其研究结果表明信息 摘既能反映系统的演化情况，还能很好地辨识系统的可持续发展状况和健康水平 ${ }^{[2]}$ 。这 一结果为乡村生产空间系统的演化规律和可持续发展能力研究提供了重要的理论源。因 此, 本文以重庆市为研究区, 以 2001-2015 年为研究时段, 基于信息摘从支持型输人熵、 压力型输出熵、氧化型代谢熵、还原型代谢熵四个方面构建乡村生产空间系统演化指标 体系，建立演化分析模型和可持续发展能力评价模型，揭示乡村生产空间系统的演化规 律和可持续发展能力，探析其协同演化过程中的相关关系，设计乡村生产空间系统的优 化路径，为乡村生产空间系统的优化调控和可持续发展提供理论指导。

\section{1 研究方法和数据来源}

\section{1 研究区概况}

重庆市 $\left(28^{\circ} 10^{\prime} \sim 32^{\circ} 13^{\prime} \mathrm{N}, 105^{\circ} 11^{\prime} \sim 110^{\circ} 11^{\prime} \mathrm{E}\right)$ 地处中国西南部，东与鄂西交界，西南 与川黔接壤，西北与川陕毗邻，兼具 “大城市、大农村、大山区、大库区、多民族” 的特 殊地域环境。全市幅员面积 $8.24 \times 10^{4} \mathrm{~km}^{2}$, 共辖 23 区 15 县; 地貌以丘陵、山地为主, 山地 占 76\%; 属亚热带季风性湿润气候, 年平均气温 $16 \sim 18{ }^{\circ} \mathrm{C}$, 常年降雨量 $1000 \sim 1450 \mathrm{~mm}$, 自然条件优越，区位优势明显。截至 2015 年末，重庆市常住人口达 $3016.55 \times 10^{4}$ 人，乡村 人口 $1178.14 \times 10^{4}$ 人; 乡村地域内从业人员 $720.5 \times 10^{4}$ 人，占总就业人员的 $42.2 \%$ 。粮食、 蔬菜、水果总产量分别为 $1154.89 \times 10^{4} \mathrm{t} 、 1780.47 \times 10^{4} \mathrm{t} 、 375.85 \times 10^{4} \mathrm{t}$ ，农林牧渔业总产值 $17381486 \times 10^{4}$ 元, 乡镇企业总产值高达 $154361000 \times 10^{4}$ 元。乡村旅游接待游客 $1.2 \times 10^{8}$ 人 次、实现综合收人 $210 \times 10^{8}$ 元, 乡村一二三产业齐头并进。完成 2200 多个农村环境连片 整治项目，乡村卫生则所普及率、农业废弃物综合利用率达 $66.2 \% 、 84.45 \%$ ，沼气池产 气总量高达 $46875.59 \times 10^{4} \mathrm{~m}^{3}$ 。实现造林面积 $22 \times 10^{4} \mathrm{hm}^{2}$, 森林覆盖率达 $45 \%$ 。同时, 乡 村生产空间系统仍面临着严峻的挑战: 乡村地域内人口众多、山地广布、农地零碎, 基 础设施、公共服务建设较为滞后; 农业源化学需氧量排放量、农业源氨氮排放量高达 117482 t、12007 t，成为仅次于生活污水的主要水污染源；农业兼业化、农村空心化、 农民老龄化现象突出，农业农村现代化正处在一个艰难的负重爬坡阶段。

\section{2 数据来源与整理}

因中国正处于第十三个五年规划执行期，为保证数据的完整性、可获取性和时效 性，本文以第十个五年规划至第十二个五年规划（2001-2015年）为研究时段。研究数据 主要包括社会经济数据和生态环境数据, 社会经济数据主要来源于《重庆统计年鉴》 （2002-2016年）、《重庆调查年鉴》(2002-2016年)、《中国农业统计资料》(2001-2015 年）和《重庆市旅游业统计公报》(2001-2015 年) 等; 生态环境数据主要来源于《中国 环境统计年鉴》(2002-2016年)、《重庆市森林资源公报》(2001-2015年) 和《重庆市环 境状况公报》(2001-2015 年) 等。此外, 部分数据为计算数据: 化肥污染排放量 $=$ 化肥施 用量 (折纯量) $\times$ 人河系数, 作物秥秆污染排放量 $=$ 某作物产量 $\times$ 某作物秸秆产出系数 $\times$ ( 1 - 秸秆利用率 $) \times$ 秸秆养分含量 $\times$ 人河系数, 畜禽养殖污染排放量 $=$ 养殖总量 $\times$ 畜禽粪便 排放系数 $\times$ 粪便中污染物平均含量 $\times$ 污染物人河系数, 具体算法参见相关文献 ${ }^{[23]}$ 。

\section{3 研究方法}

1.3.1 乡村生产空间系统“信息熵”理论

熵源于物理学, 表示大量分子的无序运动。1948年, 香农（SHANNON C E）将熵 
引人信息论并提出信息熵理论 ${ }^{[2]}$, 标志着信息摘研究的开始。经多年研究发现, 信息熵 可用于反映系统的无序程度，定量判断系统的演化方向 ${ }^{[25]}$ 。乡村生产空间系统作为复杂 开放动态的人地关系地域系统，一方面通过系统内部各要素间的相互影响与相互作用， 维持和不断打破乡村生产空间系统自身物质、信息、能量的内循环; 另一方面通过乡村 生产活动这一媒介（这一干扰媒介受乡村生产空间基底、市场需求、支农惠农政策、科 学技术水平等客观因素影响), 不断与外部环境进行物质、能量和信息交换, 表现出乡村 生产空间系统的外循环; 最终基于内外循环相互作用结果而不断运行, 甚至演化。这一 运行过程符合耗散结构系统的预定假设, 具有耗散结构特征, 是典型的耗散结构系统 ${ }^{[1]}$, 其演化过程可理解为旧的耗散结构不断解体, 新的耗散结构不断形成, 可用耗散结构系 统熵变 (包括熵流和熵产生) 予以表征。同时, 地理系统与热力学系统相似的学术观点 已得到了地理学家广泛认同 ${ }^{[26]}$ 。因此, 运用信息摘可揭示乡村生产空间系统的演化规 律。具体而言, 乡村生产空间系统与外部环境进行物质循环、能量流动和信息转换引起 熵交换, 发生熵流; 系统内本身不可逆过程, 即系统内部环境质量恶化和生态环境建设 引起熵增加, 发生熵产生; 并在外部扰动和内部涨落的影响下发生总熵变, 引起系统的 演替和变化 (图 1)。本研究借鉴城市生态系统研究成果 ${ }^{[20-22]}$, 将乡村生产空间系统 “信 息熵” 细化为支持型输人熵 $\left(\Delta_{S} S_{1}\right)$ 、压力型输出熵 $\left(\Delta_{2} S_{2}\right)$ 、氧化型代谢熵 $\left(\Delta_{i} S_{2}\right)$ 、还原 型代谢熵 $\left(\Delta_{i} S_{1}\right) 4$ 种类别熵表征，其含义见表 1 。

\subsection{2 乡村生产空间系统演化指标体系构建}

近年来, 中国乡村主体多元化、业态多样化、土地利用多功能态势趋强, 特别是党 的十九大关于乡村振兴战略的顶层设计以及 2018 年中央一号文件《中共中央国务院关于 实施乡村振兴战略的意见》的发布, 将加速乡村生产空间系统内部要素的流动及相互作 用, 进一步推动系统结构、形态与功能的不断演化。针对这一特殊现实特征, 本研究首 先系统总结城市生态系统演化、可持续发展能力等已有研究成果 ${ }^{[20-22]}$, 其次结合重庆市乡 村生产空间系统人地相互作用复杂多样、与其他省市发展水平各异和所面临关键问题不 尽相同的总体特征，再次借鉴 PSR（压力一状态一响应）模型 ${ }^{[27]}$, 基于层次分析原理 ${ }^{[28]}$, 遵循系统性、代表性和可操作性原则, 从支持型输人熵、压力型输出熵、氧化型代谢 熵和还原型代谢熵 4 个方面构建乡村生产空间系统演化指标体系，共包括 38 个指标 (表2)。

支持型输人熵指标 $\left(A_{1} \sim A_{10}\right)$ 主 要体现乡村生产空间系统内自然环境 的生产力和乡村多元主体的生产力, 可反应乡村生产空间系统的支持作 用; 压力型输出熵指标 $\left(B_{1} \sim B_{10}\right)$ 主 要体现乡村生产空间系统中乡村多元 主体使用、释放能量物质的能力, 可 反映乡村生产空间系统承担的压力; 氧化型代谢熵指标 $\left(C_{\mathrm{r}} \sim C_{8}\right)$ 主要体 现乡村生产空间系统的氧化代谢能 力, 表现为乡村生产过程中排放的废 弃物、污染物等对环境造成的负面影

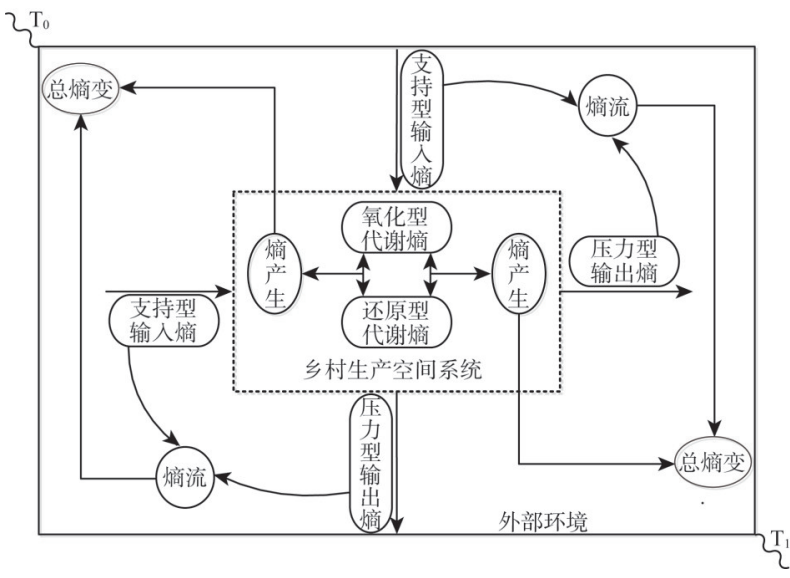

图 1 乡村生产空间系统熵变模式

Fig. 1 The entropy change mode of rural production space system 
表 1 乡村生产空间系统熵流、熵产生和总熵变的符号、公式及含义

Table 1 The symbol, formula and meaning of the entropy flow, entropy production and total entropy change of rural production space system

\begin{tabular}{|c|c|c|}
\hline 项目 & 符号与公式 & 含义 \\
\hline 支持型输人熵 & $\Delta_{e} S_{1}$ & 揭示乡村生产空间系统的支持作用 \\
\hline 压力型输出熵 & $\Delta_{e} S_{2}$ & 揭示乡村生产发展给乡村生产空间系统造成的压力 \\
\hline 氧化型代谢熵 & $\Delta_{i} S_{2}$ & 揭示乡村生产空间系统中各类生产行为对自然环境的负面影响 \\
\hline 还原型代谢熵 & $\Delta_{i} S_{1}$ & 揭示人类对乡村生产空间系统的环境保护和污染物治理能力 \\
\hline 熵流 & $\Delta_{e} S_{2}-\Delta_{e} S_{1}$ & $\begin{array}{l}\text { 揭示乡村多元主体的生产活动与环境保护之间的互动作用, 主要反映乡 } \\
\text { 村生产空间系统对乡村生产发展的承载力, 表征系统的协调性 }\end{array}$ \\
\hline 熵产生 & $\Delta_{i} S_{2}-\Delta_{i} S_{1}$ & $\begin{array}{l}\text { 揭示乡村生产空间系统内部环境污染产生与环境净化的互动作用, 反映 } \\
\text { 乡村生产空间系统在代谢过程中的还原再生能力, 表征系统的活力 }\end{array}$ \\
\hline 总熵变 & $\left(\Delta_{e} S_{2}-\Delta_{e} S_{1}\right)+\left(\Delta_{i} S_{2}-\Delta_{i} S_{1}\right)$ & $\begin{array}{l}\text { 揭示乡村生产空间系统的总体演进方向, 表征系统的有序度和健康水 } \\
\text { 平。系统总熵变为 “正摘”, 表明系统无序度增加; 系统总熵变为 “负 } \\
\text { 熵”, 表明系统有序度增强 }\end{array}$ \\
\hline
\end{tabular}

响；还原型代谢熵指标 $\left(D_{1} \sim D_{10}\right)$ 主要体现乡村生产空间系统的还原代谢能力，表现为 人类对乡村生产空间系统的环境保护及对各类污染物治理。

\subsection{3 乡村生产空间系统演化分析和可持续发展能力评价模型}

(1) 数据标准化处理

本文数据标准化处理主要涉及乡村生产空间系统演化分析和乡村生产空间系统可持 续发展能力评价两个方面。一方面，因构建 “信息摘” 熵变模型时已经将各类型熵指标 进行了矢量化，在数据标准化时无需区分正向指标和负向指标，故采用Z-score标准化 法。另一方面，乡村生产空间系统可持续发展能力评价模型并未对各类别熵指标进行矢 量化，故在数据标准化时需区分正向指标和负向指标：支持型输人熵指标和还原型代谢 熵指标属负熵指标，即这些指标的增大将使乡村生产空间系统朝健康有序方向演化，为 正向指标; 压力型输出指标和消费代谢型指标属正熵指标, 即这些指标的增大将使乡村 生产空间系统朝混乱无序方向演化，为负向指标，故采用极差标准化法。

(1) Z-score标准化法

$$
z=\frac{x-u}{\sigma}
$$

式中: $z$ 为指标标准值; $x$ 为指标原始值; $u$ 为指标数据均值; $\sigma$ 为指标数据标准差。

(2) 极差标准化法

当 $X_{i j}$ 是正向指标时:

当 $X_{i j}$ 是负向指标时:

$$
\begin{aligned}
Z_{i j} & =\frac{X_{i j}-\min X_{i j}}{\max X_{i j}-\min X_{i j}} \\
Z_{i j} & =\frac{\max X_{i j}-X_{i j}}{\max X_{i j}-\min X_{i j}}
\end{aligned}
$$

式中： $Z_{i j}$ 为标准化之后的指标值; $X_{i j}$ 为第 $i$ 项指标的第 $j$ 年的原始数值。

(2) 乡村生产空间系统演化分析模型

根据信息熵理论, 对于一个不确定性系统, 采用随机变量 $X$ 表示其状态特征。对于 离散随机变量, 若 $x$ 取值为 $X=\left\{x_{1}, x_{2}, \cdots, x_{n}\right\}(n \geqslant 2)$, 每一取值 对应概率 $P=\left\{p_{1}, p_{2}, \cdots, p_{n}\right\}\left(0 \leqslant p_{i} \leqslant 1, i=1,2, \cdots, n\right)$, 且有 $\sum_{i=1}^{n} P_{i}=1$, 则该系统的信息熵为: 
表 2 乡村生产空间系统演化指标体系

Table 2 The index system of rural production space system evolution

\begin{tabular}{|c|c|c|c|c|c|}
\hline 目标层 & 准则层 & 次准则层 & 要素层 & 单位 & 权重 \\
\hline \multirow{38}{*}{$\begin{array}{l}\text { 乡村生产空间 } \\
\text { 系统演化分析 }\end{array}$} & 熵流 & 支持型输人摘指标 $(A)$ & 粮食总产量 $A_{1}$ & $\mathrm{t}$ & 0.019 \\
\hline & & & 蔬菜总产量 $A_{2}$ & $\mathrm{t}$ & 0.104 \\
\hline & & & 水果总产量 $A_{3}$ & $\mathrm{t}$ & 0.063 \\
\hline & & & 水产品总产量 $A_{4}$ & $\mathrm{t}$ & 0.124 \\
\hline & & & 肉类总产量 $A_{5}$ & $\mathrm{t}$ & 0.073 \\
\hline & & & 农林牧渔业总产值 $A_{6}$ & 元 & 0.096 \\
\hline & & & 乡镇企业总产值 $A_{7}$ & 元 & 0.101 \\
\hline & & & 乡村旅游综合收人 $A_{8}$ & 元 & 0.173 \\
\hline & & & 农村居民人均纯收人 $A_{9}$ & 元/人 & 0.115 \\
\hline & & & 农产品进出口总值 $A_{10}$ & 万USD & 0.132 \\
\hline & & 压力型输出熵指标 $(B)$ & 乡村地域内从业人口数量 $B_{1}$ & 人 & 0.058 \\
\hline & & & 乡村旅游接待游客人次 $B_{2}$ & 人次 & 0.064 \\
\hline & & & 农村居民家庭经营费用支出 $B_{3}$ & 元/人 & 0.052 \\
\hline & & & 农林水事务财政支出 $B_{4}$ & 元 & 0.095 \\
\hline & & & 第一产业能源终端消耗量 $B_{5}$ & $\mathrm{t}$ 标准煤 & 0.097 \\
\hline & & & 农业用水量 $B_{6}$ & $\mathrm{~m}^{3}$ & 0.097 \\
\hline & & & 农用化肥施用量 $B_{7}$ & $\mathrm{t}$ & 0.189 \\
\hline & & & 农膜使用量 $B_{8}$ & $\mathrm{t}$ & 0.121 \\
\hline & & & 农药使用量 $B_{9}$ & $\mathrm{t}$ & 0.064 \\
\hline & & & 乡村生产用电量 $B_{10}$ & $\mathrm{~kW} \cdot \mathrm{h}$ & 0.163 \\
\hline & 熵产生 & 氧化型代谢熵指标 $(C)$ & 化肥污染排放量 $C_{1}$ & $\mathrm{t}$ & 0.149 \\
\hline & & & 作物秸秆污染排放量 $C_{2}$ & $\mathrm{t}$ & 0.135 \\
\hline & & & 畜禽养殖污染排放量 $C_{3}$ & $\mathrm{t}$ & 0.136 \\
\hline & & & 农业源化学需氧量排放量 $C_{4}$ & $\mathrm{t}$ & 0.112 \\
\hline & & & 农业源化学氨氮排放量 $C_{5}$ & $\mathrm{t}$ & 0.132 \\
\hline & & & 乡镇企业废水排放量 $C_{6}$ & $\mathrm{t}$ & 0.127 \\
\hline & & & 乡镇企业废气排放量 $C_{7}$ & $\mathrm{t}$ & 0.088 \\
\hline & & & 乡镇企业固体废弃物排放量 $C_{8}$ & $\mathrm{t}$ & 0.121 \\
\hline & & 还原型代谢熵指标 $(D)$ & 森林覆盖率 $D_{1}$ & $\%$ & 0.112 \\
\hline & & & 自然保护区占比 $D_{2}$ & $\%$ & 0.085 \\
\hline & & & 退耕还林率 $D_{3}$ & $\%$ & 0.058 \\
\hline & & & 沼气池产气总量 $D_{4}$ & $\%$ & 0.139 \\
\hline & & & 农业废弃物综合利用率 $D_{5}$ & $\mathrm{~m}^{3}$ & 0.083 \\
\hline & & & 乡村卫生则所普及率 $D_{6}$ & $\%$ & 0.092 \\
\hline & & & 水土流失治理率 $D_{7}$ & $\%$ & 0.109 \\
\hline & & & 乡村生产废水无害化处理率 $D_{8}$ & $\%$ & 0.063 \\
\hline & & & 乡村环保投资占 GDP 比率 $D_{9}$ & $\%$ & 0.115 \\
\hline & & & 乡村累计粪便无害化处理率 $D_{10}$ & $\%$ & 0.144 \\
\hline
\end{tabular}




$$
S=-\sum_{i=1}^{n} p_{i} \cdot \ln \left(p_{i}\right)
$$

式中： $S$ 为不确定系统的信息熵； $p_{i}$ 是离散随机变量 $X$ 的概率。

对乡村生产空间系统中 $m$ 个年份 $n$ 个评价指标进行评价，则系统年份信息熵 $\Delta S$ 可 表示为:

$$
\Delta S=-\frac{1}{\ln m} \sum_{i=1}^{n} \frac{q_{i j}}{q_{j}} \cdot \ln \frac{q_{i j}}{q_{j}}
$$

式中： $\Delta S$ 为支持型输人熵、压力型输出熵、氧化型代谢熵和还原型代谢熵; $q_{i j}$ 为指标 原始数据的标准化值; $q_{j}$ 为第 $j$ 年指标标准化值的求和, 即 $q_{j}=\sum_{i=1}^{n} q_{i j}(i=1,2, \cdots$, $n ; j=1,2, \cdots, m)$ 。

(3) 乡村生产空间系统可持续发展能力评价模型

熵权法是根据指标的变异程度，客观地计算出各指标的权重值，既可以克服主观赋 权法无法避免的随机性、臆断性问题，还可以有效解决多指标变量间信息的重叠问题， 能够深刻反映出指标信息熵值的效用价值。故本文运用熵权法确定指标权重 $W_{i}$ (表2)。

通过信息熵的衍生，可以把系统中的多维信息进行量化与综合，结合各指标标准化 值、权重，采用加权求和法计算乡村生产空间系统可持续发展能力得分:

$$
G=\sum_{i=1}^{n} W_{i} \cdot X_{i}
$$

式中: $G$ 为可持续发展能力得分; $W_{i}$ 为第 $i$ 项指标的权重; $X_{i}$ 为第 $i$ 项指标的标准化 值。可持续发展能力得分越高，表明乡村生产空间系统可持续发展状况越好。

\subsection{4 模型结果}

（1）演化熵变测算。根据式（1）对选取的指标数据进行标准化处理，并通过式 （4）计算出 2001-2015年重庆市乡村生产空间系统演化的熵变结果（表3）。

(2) 可持续发展能力得分测算。根据式（2）对选取的指标数据进行标准化处理，并 通过式（5）计算出2001-2015年重庆市乡村生产空间系统可持续发展能力得分（图2）。

\section{2 结果分析}

\section{1 乡村生产空间系统演化的熵变时序分析}

乡村生产空间系统总熵变呈下降趋势，系统有序度不断提高，结构和功能不断优 化, 总体上朝健康水平演变（表 3)。这一特征是熵流和熵产生共同作用的结果，体现了 不同阶段熵流和熵产生间的优势度。

2.1.1乡村生产空间系统熵流呈下降趋势, 下降幅度由弱增强, 系统的承载力、协调性愈渐 增强

2001-2011年熵流下降幅度较缓，乡村生产空间系统的承载力、协调性增强趋势较 弱（表3）。究其原因：2001-2011年，一方面重庆市正处于城市化快速发展时期，粮食单 产提升难、播种面积非自然减少，粮食总产量常年为 $1000 \times 10^{4} \mathrm{t}$ 左右，种植结构仍以粮 食作物为主, 蔬菜、水果等经济作物平均年增长量分别仅为 $57.09 \times 10^{4} \mathrm{t} 、 16.23 \times 10^{4} \mathrm{t}$, 水 产养殖规模化程度低、主要为散户养殖, 平均年增长量仅为 $7148.85 \mathrm{t}$; 乡镇企业同构化 严重、缺乏科学的管理体系，乡镇企业总产值平均年增长量仅为 $4792378.27 \times 10^{4}$ 元，且 
表 $32001-2015$ 年重庆市乡村生产空间系统摘变

Table 3 The entropy change of rural production space system in Chongqing from 2001 to 2015

\begin{tabular}{|c|c|c|c|c|c|c|c|c|c|c|c|c|c|c|c|}
\hline \multirow{2}{*}{ 项目 } & \multicolumn{15}{|c|}{ 年份 } \\
\hline & 2001 & 2002 & 2003 & 2004 & 2005 & 2006 & 2007 & 2008 & 2009 & 2010 & 2011 & 2012 & 2013 & 2014 & 2015 \\
\hline 支持型输人熵 & 0.343 & 0.341 & 0.346 & 0.345 & 0.344 & 0.315 & 0.335 & 0.338 & 0.337 & 0.344 & 0.359 & 0.367 & 0.377 & 0.387 & 0.393 \\
\hline 压力型输出熵 & 0.360 & 0.358 & 0.357 & 0.348 & 0.345 & 0.346 & 0.344 & 0.346 & 0.350 & 0.350 & 0.367 & 0.364 & 0.359 & 0.346 & 0.344 \\
\hline 氧化型代谢熵 & 0.422 & 0.417 & 0.408 & 0.406 & 0.405 & 0.407 & 0.403 & 0.398 & 0.395 & 0.377 & 0.362 & 0.346 & 0.339 & 0.336 & 0.332 \\
\hline 还原型代谢熵 & 0.218 & 0.231 & 0.238 & 0.251 & 0.257 & 0.279 & 0.270 & 0.270 & 0.269 & 0.281 & 0.261 & 0.273 & 0.272 & 0.276 & 0.273 \\
\hline 熵流 & 0.017 & 0.017 & 0.011 & 0.003 & 0.001 & 0.031 & 0.009 & 0.008 & 0.013 & 0.006 & 0.008 & -0.003 & -0.018 & -0.041 & -0.049 \\
\hline 熵产生 & 0.204 & 0.186 & 0.170 & 0.155 & 0.148 & 0.128 & 0.133 & 0.128 & 0.126 & 0.096 & 0.101 & 0.073 & 0.067 & 0.060 & 0.059 \\
\hline 总熵变 & 0.221 & 0.203 & 0.181 & 0.158 & 0.149 & 0.159 & 0.142 & 0.136 & 0.139 & 0.102 & 0.109 & 0.070 & 0.049 & 0.019 & 0.010 \\
\hline
\end{tabular}

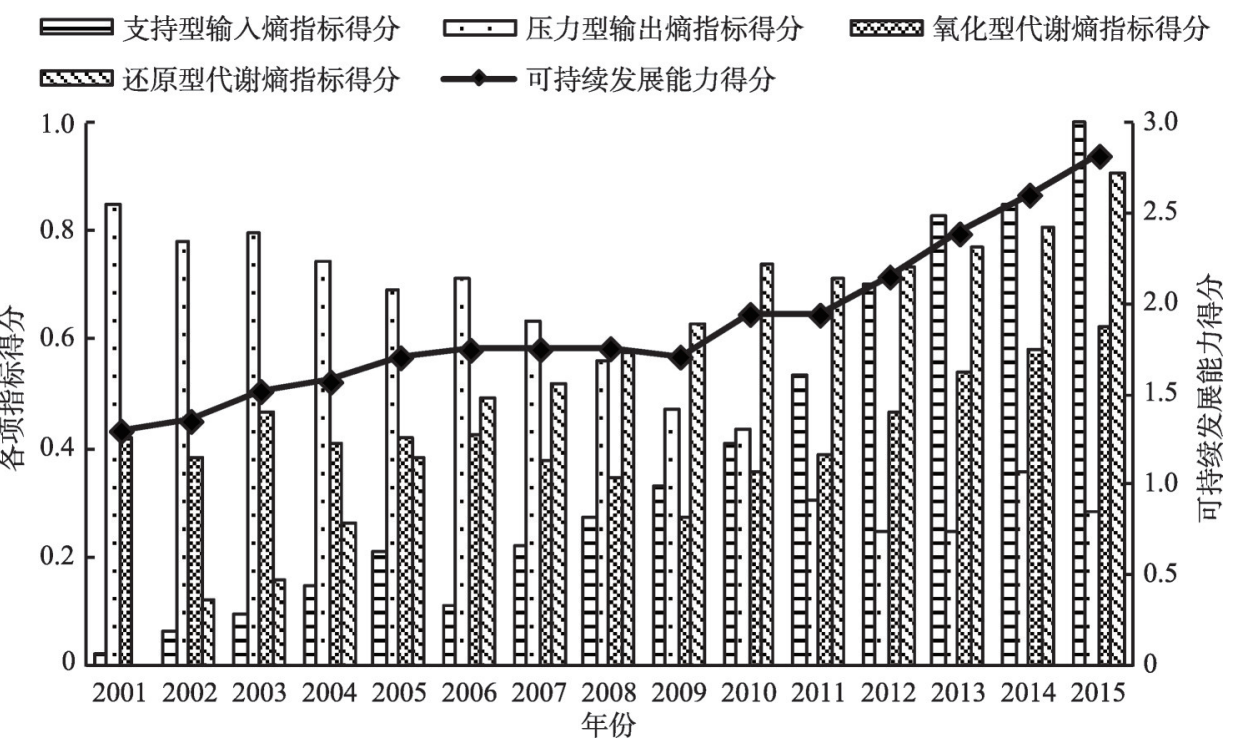

图 2 2001-2015年重庆市乡村生产空间系统可持续发展能力得分

Fig. 2 The score of sustainable development capacity of rural production space system in Chongqing from 2001 to 2015

乡村旅游处于发展初期、综合收人平均年增长量仅为 $10.38 \times 10^{8}$ 元; 乡村产业发展水平较 低，农林牧渔业总产值、农村居民人均纯收人平均年增长量分别仅为 $758332.10 \times 10^{4}$ 元、 409.93 元/人；致使乡村生产空间系统的支持作用提升幅度较小。另一方面，这一时期乡村 生产发展多以牺牲环境为代价、以增加投人来提高产出, 第一产业能源终端消耗量、乡村 生产用电量和农业用水量平均年增长量分别高达 $8.88 \times 10^{4} \mathrm{t}$ 标准煤、36596.91 $\times 10^{4} \mathrm{~kW} \cdot \mathrm{h}$ 和 $0.51 \times 10^{8} \mathrm{~m}^{3}$; 粮食、蔬菜、水果等农作物产量的增长主要依靠农资产品的使用，化肥、 农膜、农药使用量平均年增长量分别高达 $2.09 \times 10^{4} \mathrm{t} 、 0.18 \times 10^{4} \mathrm{t} 、 0.01 \times 10^{4} \mathrm{t}$; 同时, 2007 年重庆市被批成立统筹城乡综合配套改革试验区，各级政府对乡村生产的财政支持 力度加大、逐年上调农林水事务财政支出，农民抓住时机增加农村居民家庭经营费用支 出, 各级政府、农民的经济压力加重; 致使乡村生产活动给乡村生产空间系统带来压力 的减小趋势较弱。两方面共同作用促使熵流下降速度放缓。

2011-2015 年熵流下降幅度增大，且 2012-2015 年熵流由正值变为负值，乡村生产空 
间系统的承载力、协调性增强趋势显著（表3)。究其原因：2011-2015年，一方面重庆市 着力推进乡村一二三产业跨界融合, 深化农业供给侧结构性改革, 在保障粮食产量不少 于 $1100 \times 10^{4} \mathrm{t}$ 的基础上，农业逐步由 “生产导向”转向 “消费导向”，发展特色效益农 业, 蔬菜、水果总产量平均年增长量分别提升至 $74.50 \times 10^{4} \mathrm{t} 、 22.94 \times 10^{4} \mathrm{t}$; 水产养殖逐步 转向规模、集中养殖，平均年增长量升至 $41052.60 \mathrm{t}$; 成立专项资金支持乡镇企业发展， 乡镇企业提质增效、总产值平均年增长量升为 $18017050.20 \times 10^{4}$ 元; 在《重庆市乡村旅游 发展规划（2013-2020年）》顶层设计下，打造城乡交融资源组团、环城郊野资源组团、 渝东北资源组团、渝东南资源组团四大板块, 全域乡村旅游步上新高度, 乡村旅游收人 平均年增长量提高至 $13.46 \times 10^{8}$ 元; 乡村一二三产业齐头并进，农林牧渔业总产值、农村 居民人均纯收人平均年增长量分别提升至 $945633.40 \times 10^{4}$ 元、 804.86 元/人；促使乡村生产 空间系统支持作用增强且幅度较大。另一方面, 2012 年中共十八大提出 “生态文明建 设” 理念, 注重乡村经济增长与生态保护协调发展, 再次强化了良好的生态环境是乡村 生产空间系统协调持续发展的基础与保障; 重庆市积极响应国家战略, 构建农业产业结 构、农民生产生活方式与农业资源环境协调发展的新格局，严控化肥、农膜、农药使用 量, 平均年增长量分别降低至 $0.43 \times 10^{4} \mathrm{t} 、 0.12 \times 10^{4} \mathrm{t} 、-0.04 \times 10^{4} \mathrm{t}$, 同时逐步建立以沼气为 主的农村清洁能源, 乡村生产能耗降低, 第一产业能源终端消耗量、乡村生产用电量、农 业用水量平均年增长量降为 $-39.07 \times 10^{4} \mathrm{t}$ 标准煤、 $15538.20 \times 10^{4} \mathrm{~kW} \cdot \mathrm{h} 、 0.46 \times 10^{8} \mathrm{~m}^{3}$; 促使 乡村生产空间系统面临的压力减缓且幅度较大。两方面共同作用促使熵流大幅度下降。

2.1.2 乡村生产空间系统熵产生呈波动下降趋势, 系统的还原再生能力趋强, 活力逐渐提升

2001-2015年，熵产生总体呈波动下降趋势，乡村生产空间系统的污染治理和净化能 力提升, 还原再生能力、活力趋强（表 3)。究其原因：2001-2015年, 一方面重庆市强化 管理与治理农业面源污染：在江津区、万州区、石柱县、黔江区等区县设立农业面源污 染定位监测国控点，贯彻执行 “一控两减三基本”，建设三峡库区重点流域和区域的农业 面源污染综合防治示范区; 开展养殖 “四清四治” 专项行动, 加强规模化畜禽养殖场的 环境执法, 采取 “先建后补” 或 “以奖代补” 的方式, 实施重点减排项目, 农业源化学 需氧量排放量、农业源化学氨氮排放量分别下降了 $27.84 \% 、 27.67 \%$; 出台作物秸秆露天 焚烧综合治理方案，改善和研发农作物秸秆综合利用技术，作物秸秆污染排放量下降了 $20.14 \%$; 强化对乡镇企业排污现状的监察力度与惩治力度，坚持 “一手抓关闭、一手抓 治理”, 乡镇企业废水排放量、乡镇企业固体废弃物排放量分别下降了 $30.43 \%$ 、 93.37\% ; 促使乡村生产空间系统本底污染被遏制，生产活动对环境污染的负面影响得到 有效控制。另一方面重庆市着力改善农村人居环境, 打造美丽宜居乡村, 开展农村环境 连片整治与 “蓝天、碧水、绿地、宁静、田园” 五大环保行动, 加大乡村环保投资, 乡 村卫生则所普及率上升了 $148.59 \%$ ，粪便、生产废水无害化处理率亦上升了 $88.50 \%$ 、 $90.18 \%$; 严格划定涉及巴南区等 30 个区县 $7466.85 \mathrm{~km}^{2}$ 的水土流失重点预防区和涉及万 州区等 21 个区县 $18723.71 \mathrm{~km}^{2}$ 的水土流失重点治理区, 分别占重庆市土地总面积的 $9.06 \%$ 和 $22.73 \%$, 水土保持成效显著, 水土流失治理率上升了 $100.32 \%$; 有计划有步骤推 进退耕还林工程、天然林保护工程，森林覆盖率、退耕还林率分别上升了 $94.81 \%$ 、 $762.63 \%$ ，同时开展农业废弃物资源化利用工作与农村沼气工程，农业废弃物综合利用 率、沼气池产气总量分别上升了 $29.33 \% 、 251.57 \%$; 促使乡村生产空间系统的环境保护和 污染物治理能力不断提高。 


\section{2 乡村生产空间系统可持续发展能力分析}

2001-2015年重庆市乡村生产空间系统可持续发展得分呈波动上升趋势，系统可持续 发展水平不断提高（图 2)。且 2001-2011 年可持续发展能力增长较为平缓，2011-2015年 增长幅度较大，主要受支持型输人熵指标得分增速变化的影响。其中，2001-2015年支持 型输人商指标得分呈逐年上升趋势，重庆市乡村生产逐渐由单一的农业生产转向一二三 产业融合生产，各项指标均呈逐年增加趋势，农林牧渔业总产值、农村居民人均纯收人 增长较为显著，增长率分别为 $303.13 \%$ 、432.91\%，乡村生产空间系统的支持作用不断增 大; 压力型输出熵指标得分呈逐年下降趋势, 乡村生产发展仍需要消耗大量的人力、物 力、财力, 除乡村地域内从业人口数量、第一产业能源终端消耗量、农药使用量分别下 降了 $33.06 \% 、 53.87 \% 、 4.71 \%$ 外，其余各项指标均呈增长趋势，乡村生产活动给自然环 境带来的压力逐渐增大; 氧化型代谢摘指标得分总体呈上升趋势, 乡村生产空间系统排 放的污染物减少、氧化代谢能力增强, 并以 2009 年为转折点, 前 9 年呈逐年下降趋势, 乡村生产活动造成的资源损耗、环境污染较为严重，后 6 年呈上升趋势，乡村生产活动 排放的污染物得到有效控制；还原型代谢摘指标得分呈逐年上升趋势，乡村生产空间系 统的环境保护和污染防治工作成效显著, 各项指标均呈逐年增长趋势, 退耕还林率、沼 气池产气总量、乡村卫生则所普及率和水土流失治理率增长较为显著, 增长率分别为 $762.63 \% 、 251.57 \% 、 148.59 \%$ 和 $100.32 \%$ ，系统的还原能力不断增强。

\section{3 乡村生产空间系统摘变与可持续发展能力协同演化的相关分析}

通过运用相关性分析中的 Person相关系数，定量揭示 2001-2015年重庆市乡村生产空 间系统熵变与可持续发展能力之间协同演化过程中的相关关系（表4)：(1) 可持续发展 能力得分与支持型输人摘、还原型代谢摘呈正相关关系，表明为乡村生产空间系统提供 充足的资金、农产品、工商旅服务等物质、能量、信息输人需求保障，提高乡村生产空 间系统的环境治理和净化能力，可以有效增强乡村生产空间系统可持续发展能力; (2) 可持续发展能力得分与压力型输出熵、氧化型代谢熵之间呈负相关关系，表明能源、劳 动力、农资产品等乡村生产要素的过度投人、粗放化使用, 农业面源污染以及乡镇企业 “三废” 等污染物的大量排放，将会弱化乡村生产空间系统可持续发展能力；(3) 可持续 发展能力得分与熵流、摘产生和总摘变呈显著的负相关关系，表明乡村生产空间系统的 协调性和活力不断提升、朝有序方向演进，将会提升乡村生产空间系统可持续发展能力。

\section{4 基于熵权与指标时间序列变化的乡村生产空间系统优化}

\subsection{1 基于支持型输人熵指标的乡村生产空间系统优化}

乡村旅游综合收人、农产品进出口总值、水产品总产量和农村居民人均纯收人 4 项 指标的熵权大, 研究期间增长幅度较大, 对重庆市乡村生产空间系统承载力的贡献率较 高。通过坚持以农为本、融合发展，开发农业观光、农耕体验、休闲采摘等特色鲜明的 乡村旅游产品，建设特色旅游村镇，推动特色民宿、休闲农庄和农家乐等集群化发展; 创新农产品 “供给侧”，打开新市场，健全与完善农产品质检机制，提高进出口农产品档 次; 提高水产养殖的科技含量, 发展规模化、集中化水产养殖业; 提高农民职业技能, 延伸就业渠道，实施支农惠农政策，拓宽农民收人来源。

粮食总产量、水果总产量和肉类总产量 3 项指标的熵权较小，研究期间增长幅度较 小，是重庆市乡村生产空间系统承载力提升的主攻方向。以永久基本农田划定为契机， 建设高标准农田、改造中低产田，严格实施耕地占补平衡制度，改进粮食生产技术，确 
表 4 2001-2015 年重庆市乡村生产空间系统熵变与可持续发展能力相关性

Table 4 The correlation between entropy change and sustainable development capacity of rural production space system in Chongqing from 2001 to 2015

\begin{tabular}{lcccccccc}
\hline $\begin{array}{c}\text { 相关性 } \\
\text { Pearson系数 })\end{array}$ & $\begin{array}{c}\text { 支持型 } \\
\text { 输人熵 }\end{array}$ & $\begin{array}{c}\text { 压力型 } \\
\text { 输出熵 }\end{array}$ & $\begin{array}{c}\text { 氧化型 } \\
\text { 代谢熵 }\end{array}$ & $\begin{array}{c}\text { 还原型 } \\
\text { 代谢熵 }\end{array}$ & 熵流 & 熵产生 & 总熵变 & $\begin{array}{c}\text { 可持续发展 } \\
\text { 能力得分 }\end{array}$ \\
\hline 支持型输人熵 & 1.000 & 0.142 & $-0.878^{* *}$ & 0.216 & $-0.934^{* *}$ & $-0.699^{* *}$ & $-0.826^{* *}$ & $0.878^{* *}$ \\
压力型输出熵 & 0.142 & 1.000 & -0.112 & -0.402 & 0.222 & 0.087 & 0.139 & -0.041 \\
氧化型代谢熵 & $-0.878^{* *}$ & -0.112 & 1.000 & $-0.607^{*}$ & $0.824^{* *}$ & $0.945^{* *}$ & $0.967^{* *}$ & $-0.981^{* *}$ \\
还原型代谢熵 & 0.216 & -0.402 & $-0.607^{*}$ & 1.000 & -0.358 & $-0.833^{* *}$ & $-0.727^{* *}$ & $0.625^{*}$ \\
熵流 & $-0.934^{* *}$ & 0.222 & $0.824^{* *}$ & -0.358 & 1.000 & $0.720^{* *}$ & $0.864^{* *}$ & $-0.879^{* * *}$ \\
熵产生 & $-0.699^{* *}$ & 0.087 & $0.945^{* *}$ & $-0.833^{* *}$ & $0.720^{* *}$ & 1.000 & $0.972^{* *}$ & $-0.939^{* *}$ \\
总熵变 & $-0.826^{* *}$ & 0.139 & $0.967^{* *}$ & $-0.727^{* *}$ & $0.864^{* *}$ & $0.972^{* *}$ & 1.000 & $-0.982^{* *}$ \\
可持续发展能力得分 & $0.878^{* *}$ & -0.041 & $-0.981^{* *}$ & $0.625^{*}$ & $-0.879^{* *}$ & $-0.939^{* *}$ & $-0.982^{* *}$ & 1.000 \\
\hline
\end{tabular}

注：相关性分析采用Person相关系数; “* “分别表示在 $0.01 、 0.05$ 水平（双侧）上显著相关。

保粮食稳产增收; 调整水果品种结构, 以柑橘为重点, 培育名品, 推动果品产业化发 展; 培育特色养殖业，应用健康养殖新技术，构建养殖业产业集群。

2.4.2 基于压力型输出熵指标的乡村生产空间系统优化

农用化肥施用量、乡村生产用电量、农膜使用量、农业用水量和第一产业能源终端 消耗量 5 项指标的熵权较大。研究期间内除第一产业能源终端消耗量外其余 4 项指标均呈 增长趋势, 是缓解重庆市乡村生产空间系统压力的重要突破口。推广测土施肥、配方施 肥和化肥深施等技术，增施有机肥料、栽种绿肥; 制定切实可行的阶梯电价，实施节电 激励措施, 采用节电设备; 做好废弃农膜的清除、回收、处理, 开展易降解塑料的示范 推广和塑料薄膜代替品的应用，进行农膜的 “私人定制”，开发生产功能性农膜，减轻 “白色污染”; 发展节水农业, 推广滴灌和喷灌技术，探索智慧灌溉，根据农作物需水的 要求, 适时适量地灌水, 做到计划用水、优化配水。

\subsection{3 基于氧化型代谢熵指标的乡村生产空间系统优化}

化肥污染排放量、作物秸秆污染排放量、畜禽养殖污染排放量和农业源化学氨氮排 放量 4 项指标的熵权较大。研究期间内除畜禽养殖污染排放量和农业源化学氨氮排放量 外其余 2 项指标均呈增长趋势，是重庆市乡村生产空间系统氧化代谢功能提升的重点治 理方向。开展农业面源污染治理工作和土壤污染防治行动, 界定化肥生产过程中相关有 害物质的允许量标准，法律手段与行政手段并举防治化肥污染，严格化肥污染物质的监 测检查，防止化肥带人土壤过量的有害物质，同时使用氮肥增效剂，提高化肥的肥效并 缓解土壤污染; 加强露天焚烧秸秆管理, 大力研发、推广秸秆易腐化农作物品种和秸秆 还田还土技术，提高秸秆还田还土效率，推广新型秸秆气化炉，鼓励农户对秸秆回收资 源化利用，减少秸秆燃烧对大气的污染。

2.4.4 基于还原型代谢熵指标的乡村生产空间系统优化

乡村累计粪便无害化处理率、沼气池产气总量、乡村环保投资占 GDP 比率和森林覆 盖率 4 项指标的熵权较大, 研究期间均有较大幅度的增长, 对重庆市乡村生产空间系统 还原代谢功能提高的贡献突出。借助生物技术，培育新良种，减少饲料量与排便量，同 时推动畜禽粪便减量化、资源化、无害化处理; 适当提高沼气补助标准, 调动农民建池 积极性，构建庭院型、生态农业型、生态家园养殖型等农村沼气发展模式，促进沼气发 
展由小型沼气向农户集中供气的大中型沼气转变; 建立健全政府、企业、社会、农户多 元化资金参与乡村环境保护的投融资机制, 优化乡村环保投人结构, 多举措落实乡村环 保资金; 稳步推进天然林保护工程，严守林地保护红线，强化育林工作人员职业技能培 训, 严禁滥砍滥伐。

退耕还林率、乡村生产废水无害化处理率和农业废弃物综合利用率 3 项指标的熵权 较小, 研究期间增长幅度较小, 是重庆市乡村生产空间系统还原代谢功能提升的关键。 提高退耕还林政策补助标准, 科学制定退耕还林规划, 因地制宜选择树种, 多部门联 动、高效稳步推进退耕还林工作; 增修污水处理站, 拓宽污水处理覆盖面, 研发污水处 理、污水再利用新技术; 以就地消纳、能量循环、综合利用为主线, 着力探索农业废弃 物资源化利用的有效治理模式。

\section{3 结论与讨论}

\section{1 结论}

（1）2001-2015年重庆市乡村生产空间系统总熵变呈下降趋势，系统的有序度不断提 高, 结构和功能不断优化, 总体朝健康态势演进。其中, 熵流总体呈下降趋势, 系统的 协调性愈渐增强，且 2001-2011 年熵流下降幅度较缓，2011-2015年熵流下降幅度较大; 熵产生呈波动下降趋势, 系统内环境污染得到有效控制、环境净化能力提高, 还原再生 能力得以提升、活力不断增强。

（2）2001-2015年重庆市乡村生产空间系统可持续发展能力得分呈上升趋势，系统可 持续发展能力不断提高。其中, 支持型输入商指标得分、氧化型代谢熵指标得分和还原 型代谢熵指标得分均呈上升趋势，压力型输出熵指标得分呈下降趋势; 虽然重庆市乡村 生产发展给乡村生产空间系统造成的压力逐渐增大，但是乡村生产空间系统的支持作用 愈渐增大, 氧化代谢功能和还原代谢功能不断增强, 系统总体朝着可持续方向发展。

(3) 可持续发展能力得分与支持型输人商、还原型代谢熵正相关，与压力型输出 熵、氧化型代谢摘负相关, 与熵流、摘产生、总熵变负相关。在乡村生产发展过程中, 为乡村生产空间系统提供充足的资金、农产品、工商旅服务等物质、能量和信息输人需 求保障, 提高系统的环境治理和净化能力, 可以有效增强系统可持续发展能力; 而能 源、劳动力、农资产品等乡村生产要素的过度投人、粗放化使用, 乡村生产污染物的大 量排放, 将会阻碍系统可持续发展能力的提升; 乡村生产空间系统协调性和活力的增 强、有序度的提升，将会推动系统可持续发展能力的提高。

\section{2 讨论}

（1）推进农业导向转变，加快三产深度融合，助推产业兴旺。推进农业由“生产导 向”转向 “消费导向”, 在坚守粮食安全 “三条底线” 的基础上, 适度调减低效粮食种植 面积, 以粮食生产功能区和重要农产品生产保护区为重点、以涪陵枚菜、荣昌猪、奉节 脐橙等品牌为基础，建立 “农户一企业一科技”一体化立体农业开发模式；发展 “特 （乡土特色）优（绿色生态环保）名（传统文化内涵）” 等农产品加工业, 培育农村微 商、电商, 延长农产品产业链; 充分利用重庆市大乡村、大田园、大生态的资源优势, 以现有采摘、赏花、品果、垂钧、农事体验、农耕文化为本底, 发展全域乡村旅游, 实 现 “乡村旅游+”, 推进 “一村一品、多村一品、一乡一品、一县一业” 新业态, 构建 “吃、住、行、游、购、娱” 综合化的乡村旅游产业体系，促进乡村一二三产业深度融合。 
（2）控制污染源，扩大清洁能源覆盖面，提升资源循环利用能力，营造绿色生产氛 围，打造生态、宜业美丽乡村。科学编制重庆市农业面源污染防治规划，开展化肥农药 零增长行动和农膜回收行动，高效划定畜昺养殖禁养区、限养区、适养区 “三区”，采取 关闭搬迁、停养治理、限量饲养等方式分类治理畜禽养殖污染，严控污染企业的 “上山 下乡”，加强对 “小散乱污” 的监管，多管齐下防治乡村生产面源污染; 开展生态种植、 健康养殖等绿色行动, 发展生态循环型农业, 重点支持生态经济、循环和低碳型工业, 落实秸秆补贴政策，推广秸秆还田、秸秆有机肥、秸秆养畜等综合利用技术，加大太阳 能、沼气等可再生清洁能源应用技术的宣传力度，推动 “农户沼气” 逐步转向 “产业沼 气”，采用“猪一沼一果” “猪一沼一菜” “猪一沼一鱼” 等生态种养模式，打造生态、宜 业美丽乡村。

（3）宜地施策，建立健全以产业带动农民增收、农村增效的长效机制，发挥乡村资 源内动力，确保农民生活富裕。立足本地产业实际，以市场为导向、效益为中心、增收 为目标，充分尊重农民意愿，优化调整产业结构，挖掘产业增收潜力，强化柑橘、生态 渔业、草食牲畜、茶叶、榨菜、中药材、调味品七大特色产业链建设, 把资源优势转化 成产业优势、经济优势，充分发挥乡村资源内动力，以龙头企业带动产业发展和农民增 收; 探索资本和农民的利益联结机制，积极培育 “以农业企业为龙头、农民合作社为纽 带、家庭农场为基础” 的一体化现代农业经营组织，创新采用“公司+基地十农户”“公 司+基地+合作社+农户” 等经营模式; 积极引导传统农户和新型农业经营主体立足地区 特色资源建设特色效益农业基地，开办粮食加工、果蔬加工和食用畜产品加工等农产品 加工企业，推动产业增值，实现农民增收、农村增效。

\section{参考文献(References):}

[1] 王成, 李影颖. 乡村生产空间系统的概念性认知及其研究框架. 地理科学进展, 2017, 36(8): 913-923. [WANG C, LI H Y. Conceptual and research frameworks of rural production space system. Progress in Geography, 2017, 36(8): 913923.]

[2] 龙花楼. 中国乡村转型发展与土地利用. 北京: 科学出版社, 2012. [LONG H L. Rural Transformation and Land Use in China. Beijing: Science Press, 2012.]

[3] 王国刚, 刘合光, 钱静斐, 等. 中国农业生产经营主体变迁及其影响效应. 地理研究, 2017, 36(6): 1081-1090. [WANG G G, LIU H G, QIAN J F, et al. The change of agricultural business entities and its influence effect. Geographical Research, 2017, 36(6): 1081-1090.]

[4] LONG H L, LIU Y S, Wu X Q, et al. Spatio-temporal dynamic patterns of farmland and rural settlements in Su-XiChang region: Implications for building a new countryside in coastal China. Land Use Policy, 2009, 26(2): 322-333.

[5] 李玉恒, 刘彦随. 中国城乡发展转型中资源与环境问题解析. 经济地理, 2013, 33(1): 61-65. [LI Y H, LIU Y S. Investigation of the resource \& environment issues in the urban-rural transition in China. Economic Geography, 2013, 33(1): 61-65.]

[6] 王成, 马小苏, 唐宁, 等. 农户行为视角下的乡村生产空间系统运行机制及重构启示. 地理科学进展, 2018, 37(5): 636-646. [WANG C, MA X S, TANG N, et al. Operational mechanism and restructuring of rural production space system from the perspective of farming household behavior. Progress in Geography, 2018, 37(5): 636-646.]

[7] ANTROP M. Landscape change: Plan or chaos. Landscape and Urban Planning, 1998, 41(3-4): 155-161.

[8] MARTIN M A, TAGUAS F J. Fractal modeling, characterization and simulation of particle size distribution in soil. Proceedings of the royal society of London. Series A, 1998, 454(1973): 1457-1468.

[9] LARSEN T A, GUJER W. The concept of sustainable urban water management. Water Science and Technology, 1997, 35 (9): 3-10.

[10] HERRMANN-PILLATH C, KIRCHERT D, PAN J. Disparities in Chinese economic development: Approaches on dif- 
ferent levels of aggregation. Economic Systems, 2002, 26(1): 31-54.

[11] WELL MANN J F, REGENAUER-LIEB K. Uncertainties have a meaning: Information entropy as a quality measure for 3D geological models. Tectonophysics, 2012, 526-529(2): 207-216.

[12] 林珍铭, 夏斌, 董武娟. 基于信息熵的广东省土地利用结构时空变化分析. 热带地理, 2011, 31(3): 266-271. [LIN Z M, XIA B, DONG W J. Analysis on temporal-spatial changes of land-use structure in Guangdong province based on information entropy. Tropical Geography, 2011, 31(3): 266-271.]

[13] 王晓娇, 陈英, 齐鹏, 等. 土地利用结构动态演变及预测研究: 以张掖市为例. 干旱区资源与环境, 2012, 26(4): 8691. [WANG X J, CHEN Y, QI P, et al. Dynamic evolution and prediction of land use structure in Zhangye. Journal of Arid Land Resources and Environment, 2012, 26(4): 86-91.]

[14] 肖思思, 吴春笃, 储金宇. 1980-2005 年太湖地区土地利用变化及驱动因素分析. 农业工程学报, 2012, 28(23): 1-10. [XIAO S S, WU C D, CHU J Y. Land use changes and driving forces in Tai Lake region from 1980 to 2005. Transactions of the Chinese Society of Agricultural Engineering, 2012, 28(23): 1-10.]

[15] 覃琳, 邱凌, 朱玉碧, 等. 基于主成分分析法的重庆市九龙坡区土地利用变化驱动机理研究. 中国农学通报, 2012, 28 (5): 240-246. [QIN L, QIU L, ZHU Y B, et al. Research on land use change and drive mechanism of Jiulongpo districtin Chongqing based on principle components analysis. Chinese Agricultural Science Bulletin, 2012, 28(5): 240-246.]

[16] 谭永忠, 吴次芳. 区域土地利用结构的信息熵分异规律研究. 自然资源学报, 2003, 18(1): 112-116. [TAN Y Z, WU C F. The laws of the information entropy values of land use composition. Journal of Natural Resources, 2003, 18(1): 112116.]

[17] 耿海青, 谷树忠, 国冬梅. 基于信息熵的城市居民家庭能源消费结构演变分析: 以无锡市为例. 自然资源学报, 2004, 19(2): 257-262. [GENG H Q, GU S Z, GUO D M. Analyses on evolution of household energy consumption structure based on information entropy. Journal of Natural Resources, 2004, 19(2): 257-262.]

[18] ZHANG Y, YANG Z, LI W. Analyses of urban ecosystem based on information entropy. Ecological Modelling, 2006, 197(1-2): 1-12.

[19] 冯健. 杭州市人口密度空间分布及其演化的模型研究. 地理研究, 2002, 21(5): 635-646. [FENG J. Modeling the spatial distribution of urban population density and its evolution in Hangzhou. Geographical Research, 2002, 21(5): 635646.]

[20] 林珍铭, 夏斌. 熵视角下的广州城市生态系统可持续发展能力分析. 地理学报, 2013, 68(1): 45-57. [LIN Z M, XIA B. Analysis of sustainable development ability of the urban ecosystem in Guangzhou city in the perspective of entropy. Acta Geographica Sinica, 2013, 68(1): 45-57.]

[21] 王龙, 徐刚, 刘敏. 基于信息熵和 $\operatorname{GM}(1,1)$ 的上海市城市生态系统演化分析与灰色预测. 环境科学学报, 2016, 36 (6): 2262-2271. [WANG L, XU G, LIU M. Analysis and forecasting of shanghai urban ecosystem evolution based on information entropy and GM $(1,1)$. Acta Scientiae Circumstantiae, 2016, 36(6): 2262-2271.]

[22] 张妍, 杨志峰, 何孟常, 等. 基于信息熵的城市生态系统演化分析. 环境科学学报, 2005, 25(8): 1127-1134. [ZHANG Y, YANG Z F, HE M C, et al. Analyses on evolution of urban complex ecosystem based on information entropy. Acta Scientiae Circumstantiae, 2005, 25(8): 1127-1134.]

[23] 张广纳, 邵景安, 王金亮, 等. 三峡库区重庆段农村面源污染时空格局演变特征. 自然资源学报, 2015, 30(7): 11971209. [ZHANG G N, SHAO J A, WANG J L, et al. Spatial and temporal variations of agricultural non-point source pollution in the Three Gorges Reservoir Area of Chongqing. Journal of Natural Resources, 2015, 30(7): 1197-1209.]

[24] SHANNON C E. A mathematical theory of communication. Bell System Technical Journal, 1948, 27(3): 379-423.

[25] JOHN E C, SHI L, SAMANTHA J. Environment as the stage for economic actors. Chinese Journal of Population, Resources and Environment, 2007, 5(1): 3-8.

[26] 徐建华, 高玉景. 地理系统演化的自组织途径、影响因素及熵标志. 系统辩证学学报, 2001, 9(3): 53-57. [XU J H, GAO Y J. The self-organizing way, influencing factors and entropy change of geographical system evolution. Chinese Journal of Systems Science, 2001, 9(3): 53-57.]

[27] KELLY K L. A systems approach to identifying decisive information for sustainable development. European Journal of Operational Research, 1998, 109(2): 452-464. 
[28] SAATY T L. Decision making-the analytic hierarchy and network process (AHP/ANP). Journal of Systems, 2004,13 (1): $1-35$.

\title{
The evolution and sustainable development capacity of rural production space system based on information entropy
}

\author{
HE Yan-zhou, WANG Cheng \\ (School of Geographical Sciences, The Laboratory of Research on Rural Human Settlements, Southwest \\ University, Chongqing Key Laboratory of Karst Environment, Chongqing 400715, China)
}

\begin{abstract}
The evolution of the rural production space system is the representation or result of the exchange of material, energy and information within and out of the rural production space system. The pros and cons of this result is the endogenous material basis and guarantee which can realize the sustainable development of the system. This study sets Chongqing as the research area with a research period from 2001 to 2015 and establishes the index system of rural production space system evolution from four aspects of support- type input entropy, pressure- type output entropy, oxidation- type metabolism entropy and deoxidization- type metabolism entropy based on information entropy. The study reveals the evolution law and sustainable development capacity of rural production space system, analyzes the relationship between entropy change and sustainable development capacity of rural production space system in the process of co-evolution, and designs the optimal path for rural production space system. The results shows that: (1) From 2001 to 2015, the entropy flow of rural production space system in Chongqing is from 0.017 to -0.049 and the entropy production is from 0.204 to 0.059 , which shows a downward trend; and the coordination and vitality of rural production space system are enhanced. The total entropy change is from 0.221 to 0.010 , showing the same trend; the degree of order in rural production space system keeps improving, and generally, it is developing towards a healthy level. (2) From 2001 to 2015, the score of sustainable development capacity of rural production space system in Chongqing is from 1.285 to 2.803, showing an upward trend. The sustainable development of the system is in a good state and is evolving towards the sustainable direction. (3) The score of sustainable development capacity is positively correlated with support- type input entropy and deoxidization- type metabolism entropy, negatively correlated with pressure- type output entropy and oxidation- type metabolism entropy, and negatively correlated with entropy flow, entropy production and total entropy change.
\end{abstract}

Keywords: rural production space system; information entropy; evolution; sustainable development capacity; Chongqing 